\title{
The Integration of Schools in Lee County, Florida
}

\section{Julian Cutler Valdivia}

University of Florida

Faculty mentor: Paul Ortiz, Department of History

\begin{abstract}
Fort Myers, Florida, is one of the fastest growing parts of the United States, yet historians have paid little attention to the area. This is especially true of the historiography surrounding Dunbar-Heights, the historically Black sections of the city. Despite having one of the largest Black communities between Tampa and Miami, there is scant information on how de jure segregation operated and ended in Southwest Florida. The research provided here fills this historiographical gap using oral histories that give us a glimpse into Florida's not-so-distant past. This methodology enables the Dunbar community to tell a new Black history of Fort Myers. Collectively, the oral histories presented in this piece help explain how Jim Crow influenced the integration of schools into the 1970s. This history of Fort Myers reminds Floridians of how connected SWFL was with the rest of the state and how deeply intertwined Florida was with the American South.
\end{abstract}

\section{Introduction}

"It is 1978 and Jim Crow is alive as ever in Fort Myers" Pat McCutcheon exclaimed. He gave the statement to Jim McGee, a reporter for the Fort Myers News Press, who was making a series on the state of Fort Myers' Black community in 1978. Here, McCutcheon is using Jim Crow as a reference to the laws that enforced segregation across America at the end of Reconstruction around 1877. It may be baffling to think that Jim Crow's influence lasted past the 1960s. We are taught in American secondary schools that segregated schooling ended in 1954 when the United States Supreme Court overruled the practice of separate but equal in Brown v. Board of Education of Topeka. We are told that racial discrimination ended when President Lyndon B. Johnson signed the Civil Rights Act of 1964 into law. Statements like these assume that after nearly a century of enforcement, the effects of segregation could be addressed through a court ruling and a bill. While integration and desegregation made African Americans equal in the eyes of the law, it did nothing to correct the decades of damage caused by Jim Crow. Both also did nothing to stop politicians in the state of Florida from delaying their implementation for as long as reasonably possible. This is especially true in Lee County, Florida, where Black citizens faced continuing challenges into the 1970 s. 


\section{The Fight to End Segregated Schooling}

In the case of Southwest Florida, the signing of the Civil Rights Act was not the end of the story, but the very beginning of one. Since 1964, African Americans in Fort Myers had been fighting for the right to attend all-White schools through the judicial system. The signing of the Civil Rights Act had motivated the National Association for the Advancement of Colored Peoples (NAACP) to challenge racism at the county level in Southwest Florida. The effort had been organized by Reverend Isadore Edwards, the pastor at Friendship Baptist Church and the President of the Lee County Chapter of the NAACP. He mobilized parents and students like Rosalind Blalock, who applied to all-White schools such as Fort Myers High School. When their acceptance was denied, the parents and the NAACP filed a lawsuit. Their argument was simple: by rejecting the Black students based on race, the Lee County Board of Public Instruction (soon to become the Lee County School Board) was openly defying the recently signed Civil Rights Act. To avert the immediate integration of its schools, the Board wrote and passed a series of measures that they hoped would appease federal judges.

The first involved integrating the teaching staff of Lee County schools. A retired Dunbar social studies teacher named George Mayo describes the plan and its implementation in an oral history. In Mayo’s (2018) interview, he states:

You want me to tell you what it was? I was working there. They sent some White teachers over here [Dunbar High School]. They put some White teachers in the Dunbar School to teach certain subjects and more than likely they were people they didn't want. So, they sent em. One was a music teacher, another - I don't know what that guy taught, but they were nice, we treated them nice... 1964 that was the so called 'integration.' They took the head of my department, the social studies department, they took her and sent her over to another school. They sent another black teacher to another school and that was integration at the time.

Mayo's retelling of events suggests that the goal of Lee County's integration was to make it seem as if progress was being made. By exchanging a small number of teachers between White and Black schools, the Board could claim they had an integrated teaching staff. As a bonus, the school district could also offload teachers for non-essential subjects while taking department heads from Dunbar.

The second measure is described by the Fort Myers News Press in their issue published October 23, 1964. It described a "grade-a-year plan" that would have desegregated $1^{\text {st }}$ grade classrooms 
and moved up yearly. Under this plan the Board could claim that they were in favor of integration and that they technically had 'integrated' schools. Lee County would also be able to claim that it started integrating classrooms before the vast majority of schools in both Florida and the American South. What this really meant was that total desegregation would have been delayed and subverted until at least 1977. If they started by integrating first graders in 1965, then it would have taken 12 whole years for the remaining segregated classes to graduate.

In addition to this, the plan also included a freedom of choice clause. The Fort Myers News Press recorded the details of the clause in their issue published February 27, 1967. The unattributed author wrote that the clause gave parents the right to decide where their child attended school until the end of the $8^{\text {th }}$ grade. After that, the student was given the choice of where to go to high school. Even if schools were being integrated yearly by grade level, Dunbar still would have remained a predominantly Black school. This is because there was a group of White parents openly hostile to the idea of integrating Dunbar High School. They mobilized after Pat Ammann reported in Fort Myers News Press on May 15 ${ }^{\text {th }}$, 1969, that integration was coming to Lee County Schools. Ammann wrote that Judge Joseph P. Lieb signed a desegregation order mandating that Dunbar High School's racial composition be 75\% White and 25\% Black. Five days later, the same reporter wrote that around "500 angry white parents" amassed in the auditorium of Lee Junior-High, where they demanded that the freedom of choice clause be upheld. One bombastic speech by a Mr. Bill W. Millican went as follows:

We all know that the courts have gotten entirely out of line. The majority should rule. We're not trying to hold anyone back - we just don't want to be pushed around. This is a national problem. The Black Manifesto calls for revolt by and central control of the country by the blacks. They would take over business and take away the money from the top businessmen and give it all to the poor. They feel they have the right to govern us. This situation is serious. We have a revolution on our hands. The federal court has pushed us one step closer to revolt.

The message was clear. Either the parents were given freedom of choice or Lee County would face an extreme backlash from White parents. On the following day, Amman wrote that Mrs. Duane Disney, a representative of the group, spoke before the Lee County School Board. Disney was quoted saying in the Fort Myers News Press, May 21, 1969, "If all means fail to get this plan (freedom of choice) for our county, we propose that you close Dunbar Junior-Senior High School." This would be the direction of the educational system in Lee County. If African Americans wanted 
equal schooling, then they would have to sacrifice Dunbar High School. Integration would only be tolerated if it were Black pupils integrating into White schools, not the opposite. By the time Dunbar High School's gates were closed, the stage was set for a crisis in Lee County schools. Telling words were written in unattributed article of the Fort Myers News Press that preceded Judge Lieb's original decision on May 11, 1969. "School officials... could do nothing better toward the real integration of these two schools... White parents would not accept forced attendance of their children at them."

\section{Integration}

At the end of 1969, all the non-graduating students of Dunbar High School were to be forcibly bused into White schools around the county. This was an unpopular practice, to say the least and debate over the practice can be found as far as January 28, 1972, in the Fort Myers News Press. In the article you can see that White and Black parents alike were dissatisfied by the idea of having their kids bused to different neighborhoods to get their educations. It was especially unpopular among Black students since places like Fort Myers High School, North Fort Myers High School, and Cypress Lake High School were all further away from Dunbar. That meant that Black students would have to wake up earlier to catch the bus for school. This was the first of many grievances that would contribute to racial disturbances in the coming semesters. Both Levon Simms (2018) and George Mayo (2018) described one of the most notable of these was a walkout at North Fort Myers High School on February $12^{\text {th }}, 1970$. They described how onlookers saw Black students exiting the school in droves as they marched across the Edison Bridge to voice their displeasure with the new status quo. As students left the school, North Fort Myers High School's principal Joe Beavo called the Lee County Sheriff's Office, who sent deputies to make sure students were not run over on the road.

This event was quite a shock to the administrators. To the surprise of everyone, the Spring of 1970 started out peacefully. While Black students were frustrated by the early mornings that came with forced busing, all seemed okay. The school's recently hired art teacher, Levon Simms (2018), talked about his feelings on his first day of class after transferring from a closed Dunbar High School. Here, he stated:

I was called to get a job going North Fort Myers High School and I headed over there. Didn't know nothing. Didn't know nobody there. Didn't know anything. Didn't even know where the classroom was. So that Monday when I got there, they gave me keys and gave me the description 
of how to get to my classroom and I got a classroom not prepared or anything. Now I was teaching $8^{\text {th }}$ grader - all day - and boy it was kind of like innovative time now, we needed to get something figured out. And that was the first day I walked in the classroom. The kids were nice! You know they were scared, I was scared, we were scared together! We started school year off really well - kids playing football together. North Fort Myers was a terror! As a matter of fact, the quarter back who was the quarterback at Dunbar became the starting quarterback at North Fort Myer High School... We were terrors man.

This was the first time that both Levon Simms and most of his students were in an integrated classroom. His comments imply that both he and his students were mutually optimistic about the future of education in Lee County. For Black faculty like Levon Simms, it was also reaffirming to see how sports helped transcend racial divisions in the school, at least for the length of the football season.

Administrators attempted to address one of the many grievances of Black students by allowing them to celebrate Black History Week, a tradition they carried over from Dunbar High School. The Fort Myers News Press mentions this in an article by reporter Dave Schmirler, published February 13, 1970, after the walkout. Superintendent Ray L. Williams spoke to the paper, claiming:

They were allowed to have a program in observance of the week. They were carrying on a program over the school intercom system every morning. A Negro student would give a resume of a famous Negro's life or an event in black history every morning. This is still continuing, and everything was going along fine. This has never been stopped.

Each of these accounts suggests that there were students, teachers, and administrators that tried at different levels to make integration as close to reality as possible.

All seemed well, but as time went on, Black students became increasingly frustrated after being discriminated against in their schools. Levon Simms (2018) also described how Black students were excluded from student-run clubs and the cheerleading team. Additionally, while Black History Week was recognized by the school, its observers were harassed. These grievances came to a boiling point when a 16-year Black male student was arrested for allegedly threatening a White female student. Supposedly he had been hanging up Black History Week posters on doors when the White student began tearing them down. An argument ensued, and Schmirler wrote that the female student claimed that he "cursed her" and "threatened to cut her 
throat." Soon a warrant was put out for his arrest and he was charged with disorderly conduct and bare assault. That was the last straw for many students. All but 80 Black students left the school in protest and marched across North Fort Myers, over the Caloosahatchee River, and into Fort Myers.

These protestors were the sons and daughters of Dunbar. We know through an oral history interview that one of them was Mattie Young (2018), the daughter of Veronica Shoemaker, who would become the first African American elected to public office in Fort Myers. When commenting on the march, she said that she was more scared of her parents than the school in the aftermath of the march. Despite the courage of the marchers, Schmirler's article tells us that the Lee County School Board "voted unanimously to suspend for 10 days all students who participated."

The reaction of the School Board becomes far more interesting when we look at the event from the perspective of the Black teachers at North Fort Myers High School. In an oral history interview, Levon Simms (2018) explained:

We were in a crazy position because we were Black teachers at the time and what do we do? Do we walk out? Do we say, 'hey we ain't walking out?' I had just got a job, you know I ain't going. Then you had one Black kid that came to my classroom. This was Renee, she didn't want to walk out because her mom was a teacher... This lady was strict also, so this kid had perfect attendance. So it was like (for Renee), do I walk out of here? If I do, my mom is going to kill me. Do I mess up my perfect attendance or what? I watched this kid be abused by teachers, by White teachers. They used the n-word. 'Go with the rest of your n...' You know. And the kid, she was cryin, just came to my classroom and sat there.

Levon Simms' account of the event tells us both about the reaction to the walkout within North Fort Myers High School and the priorities of the School Board. As Levon Simms explained in the above quote, White faculty were openly hostile towards a Black student, who had perfect attendance and had nothing to do with the walkout. The Board suspended students for peacefully walking out, but turned the other cheek towards verbally abusive faculty. Incidents like this reaffirm the fact that the Lee County School Board was not yet committed to integration, since both White and Black individuals were held to different standards in the same school. 


\section{Conclusion}

The takeaway from these events is clear. As other Southwest Florida historians like Irvin D.S. Winsboro (2012) have found, Lee County was actively trying to subvert integration efforts during the Civil Rights Era. Like other counties within the state, Lee County adopted a sophisticated approach to dealing with integration. While they never had a man like George Wallace of Alabama taking center stage to prevent White and Black students from learning together, their "Down-South strategy" was equally if not more effective. By claiming to be for 'integration,' the Lee County School Board was able to define what the term meant and what its implications were for their students.

In this case, integration meant waiting until 1977 to have fully integrated classrooms and maintain Dunbar High School as a predominantly Black school. The cardinal sin of the entire fiasco was the closure of Dunbar High School at the end of 1969. It seems odd that a brand-new school that was built six earlier had to be closed. Sure, they had a group of 500 White parents demanding that they close Dunbar High School if freedom of choice was not ensured. But would the Lee County School Board have caved if a group of 500 Black parents demanded that Judge Lieb's original order was upheld? What if, like Bill W. Millican, a Black parent claimed that the Dunbar High's closure pushed them one step closer towards revolt? Knowing racial attitudes at the time, it is hard to say the Board would have reacted similarly to these demands from Black parents. Even if White parents were apprehensive because of the school's inferior materials, new supplies could have been purchased. Those concerned about busing their children far away to Dunbar shared the burden placed predominantly on Black families. By keeping the school open they could have even prevented the walkout at North Fort Myers High School and the protests seen on other campuses. Dunbar High School was closed because Lee County never wanted true integration to begin with. Today, the same Dunbar High School that was closed in 1969 has opened its doors again. It is filled with a new generation of 'Fighting Tigers,' whose attendance embodies the hopes and dreams of a generation of students from the Civil Right Era. 


\section{References}

Ammann, P. (1969, May 15). Order signed in integration of Dunbar High. Fort Myers News Press, p. 1A.

Ammann, P. (969, May 20). Angry white parents gather to demand freedom of choice. Fort Myers News Press, p. 1A.

Ammann, P. (1969, May 21). Board, parents favor freedom of choice plan. Fort Myers News Press, p. $1 \mathrm{~A}$.

Darren, L. (1972, January 28). Some Parents Object to Proposed Busing Plan. Fort Myers News Press, p. $11 \mathrm{~A}$.

Desegregation suit is discussed here. (1967, February 27). Fort Myers News Press, p. 7A.

Integration for the Dunbar Schools. (1969, May 11). Fort Myers News Press, p. 1A.

Mayo, G. (2018, June 6). AAHP 606 [Interview by J. C. Valdivia]. Samuel Proctor Oral History Program Collection. Retrieved from P.K. Yonge Library of Florida History, University of Florida.

McGee, J. (1978, December 3). Dunbar: A community profile - About this series. Fort Myers News Press, p. 1A.

Schmirler, D. (1970, February 13). Negro students stage walkout at North High. Fort Myers News Press, p. 6A.

School Board Moves to Kill Integration Suit. (1964, October 23). Fort Myers News Press, p. 1A.

Simms, L, \& Simms, N. K. (2018, June 14). AAHP 608A [Interview by J. C. Valdivia]. Samuel Proctor Oral History Program Collection. Retrieved from P.K. Yonge Library of Florida History, University of Florida.

Winsboro, I. D. (2012). Old South, New South, or Down South? Florida and the modern civil rights movement. Morgantown, WV: West Virginia University Press.

Young, M. (2018, June 27). AAHP 611 [Interview by J. C. Valdivia]. Samuel Proctor Oral History Program Collection. Retrieved from P.K. Yonge Library of Florida History, University of Florida. 